OPEN ACCESS

Edited by:

Athanassios C. Tsikliras,

Aristotle University of Thessaloniki,

Greece

Reviewed by:

Fabio Fiorentino,

Italian National Research Council

(CNR), Italy

Nazli Demirel,

Istanbul University, Turkey

${ }^{*}$ Correspondence:

U. Rashid Sumaila

r.sumaila@oceans.ubc.ca

Specialty section:

This article was submitted to Marine Fisheries, Aquaculture

and Living Resources,

a section of the journal

Frontiers in Marine Science

Received: 07 March 2020

Accepted: 09 June 2020

Published: 15 July 2020

Citation:

Sumaila UR and Tai TC (2020)

End Overfishing and Increase

the Resilience of the Ocean to Climate

Change. Front. Mar. Sci. 7:523

doi: $10.3389 /$ fmars. 2020.00523

\section{End Overfishing and Increase the Resilience of the Ocean to Climate Change}

\author{
U. Rashid Sumaila* and Travis C. Tai
}

Fisheries Economics Research Unit, Institute for the Oceans and Fisheries, School of Public Policy and Global Affairs, The University of British Columbia, Vancouver, BC, Canada

Marine fish stocks and the ecosystems they inhabit are in decline in many parts of our ocean, including in some European waters, because of overfishing and the ecosystem effect of fishing in general. Simultaneously, climate change is disrupting the physics, chemistry and ecology of the ocean, with significant consequences on the life it holds. While the positive effects of mitigating climate change on the ocean and marine life are currently being documented, papers that examine how ending overfishing could increase ocean resilience to climate change are less common. The goal of this paper is to review the current literature and conduct an analysis that demonstrate that ending overfishing and reducing other negative ecosystem effects of fishing would make fish stocks and marine ecosystems more resilient to climate change. Our findings suggest that fish and fish stocks are no different from other living organisms and are more likely to survive external pressures when healthy.

Keywords: food webs, habitat, carbon sequestration, climate change mitigation, sustainable ocean resources

\section{HIGHLIGHTS}

- Marine fish stocks are overfished in many parts of our ocean;

- Climate change is having significant consequences on ocean life;

- We demonstrate that ending overfishing could make fish stocks more climate resilient;

- Fish and fish stocks are no different from other organisms and more likely to survive when healthy.

\section{INTRODUCTION}

We know the critical importance of the ocean for planetary function and life on Earth-mediating global weather patterns, cycling of carbon (i.e., biological carbon pump) and carbon sequestration (i.e., carbon sink), contributing almost half of the annual primary production on Earth, to name a few (Brierley and Kingsford, 2009). Marine ecosystem goods and services to human society are dependent on ocean health, yet there are many potential consequences of continuous human population growth and rising per capita consumption, in particular human-accelerated climate change and overfishing to meet global demands. 
Fish are an important part of marine ecosystems and are a central part of the marine food web where predator-prey relations both within different fish species and between fish and other marine life keep the ocean thriving. An ocean full of life is also important as a source of food and livelihood for hundreds of millions of people worldwide. Unfortunately, fish and life in the ocean in general are facing a multitude of threats, two of the biggest being overfishing and climate change.

Here, we ask and address the question: How would the reduction of overfishing as broadly defined herein increase the ability of fish stocks to withstand the impacts of climate change, making the ocean more resilient to such changes. We conduct a selected literature review and carry out an analysis that reveals the links between reducing overfishing, improvements in fish stock and marine ecosystem health and increased resilience of marine ecosystems to the effects of climate change. We use fish stocks of the European Union as an example throughout.

\section{A BROAD DEFINITION OF OVERFISHING}

We adopt a dynamic and broad concept of overfishing as captured by the concept of fishing down marine food web of Pauly et al. (2005). This concept does not only capture the fact that we are taking too many fish than nature can sustainably yield annually, we are also taking too many high tropic level and valuable fish species thereby truncating the food web (Figure 1). While both of these are happening, we are also disturbing and, in some cases, destroying ocean habitats through the use of harmful fishing gears (Chuenpagdee et al., 2003). All of these three aspects of overfishing combine to weaken the health of both fish stocks and the marine ecosystem as a whole. According to the FAO, overfishing and habitat destruction have resulted in the depletion of a third of fish stocks worldwide. Academic research has reported even higher levels of overfished stocks (e.g., Pauly et al., 2005). For fisheries in the European Union (EU), estimates suggest that "at least $40 \%$ of fish stocks in the North East Atlantic and $87 \%$ in the Mediterranean and Black Seas, are currently subject to unsustainable fishing practices (STECF, 2019)." It should be noted that these numbers are averages and that some Atlantic EU stocks have seen improvements during the past decade. At the same time the situation in other European waters are worse than the averages.

Human society has had considerable and far-reaching impacts on the global ocean (Halpern et al., 2015), and overfishing has had lasting effects on marine ecosystems and continues to be one of the greatest threats to ocean health (Pauly et al., 2005; Jackson et al., 2007; Le Quesne and Jennings, 2012; Halpern et al., 2015; Gattuso et al., 2018). Overfishing often has major ecosystem effects (Coll et al., 2008; Sumaila et al., 2019) and has even been identified as a driver of ecosystem regime shifts (Daskalov et al., 2007). As a stressor, overfishing will have negative effects on many indicators of ocean health, including biodiversity, food security, and coastal livelihoods and economies (Halpern et al., 2012). The direct impacts of overfishing can reduce fish biomass, affecting biodiversity and the sustainability of fisheries, as well

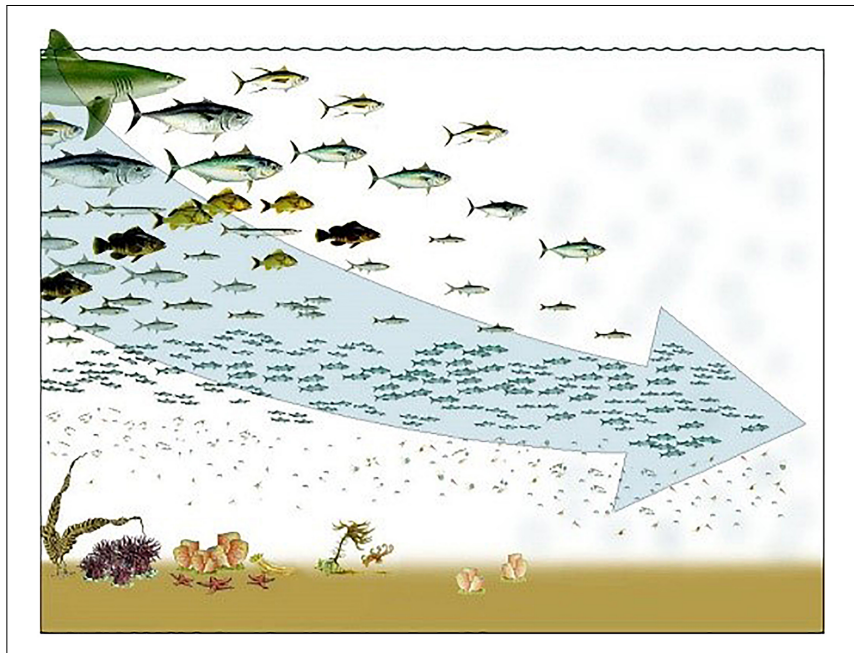

FIGURE 1 | Overfishing truncates the food web and simulates the same effects of "fishing down food webs." Figure adopted from Pauly et al. (2005).

as exacerbate the impacts of destructive fishing gear on marine ecosystems (e.g., bottom trawls). Furthermore, where overfishing is a result of illegal, unreported, or unregulated fishing, these fishing operations are often also conducted with highly impacting fishing gears-e.g., bottom trawls - that negatively affect benthic substrate (Bailey and Sumaila, 2015).

In European waters, recent reports estimate that between 40 and $70 \%$ of fish stocks are currently at an unsustainable level-either overfished or at their lower biomass limits (Froese et al., 2018; STECF, 2019). In the Mediterranean Sea, it is estimated that over $90 \%$ of stocks are overexploited (Colloca et al., 2017). Similarly, the Black Sea also sees high levels of exploitation, with continuing declines in catch (Tsikliras et al., 2015). In contrast, some northern European fish stocks are faring better, e.g., those in the Norwegian Sea and Barents Sea-due to historically well-managed fisheries some fish stocks in these waters are at maximum sustainable yield (MSY) (Gullestad et al., 2014; Froese et al., 2018). The January 1, 2020 deadline for the proposed plan to end overfishing in the EU is approaching. While there are some trends heading in the right direction, the $\mathrm{EU}$ is far from eliminating overfishing in its waters. In fact, on August 30, 2019, the EU proposed to continue overfishing past the deadline for January 1 2020, https://twitter.com/SeasAtRisk/ status/1167458264566706176.

\section{CLIMATE CHANGE IMPACTS ON FISH AND OCEAN LIFE}

Climate-related impacts on marine environments are already impacting species, populations, and ecosystems (Pörtner et al., 2014). Figure 2 provides a quick summary of the channels through which climate change can impact marine ecosystems and life. Responses to environmental change for marine organisms is largely determined by physiological tolerance, and they respond 


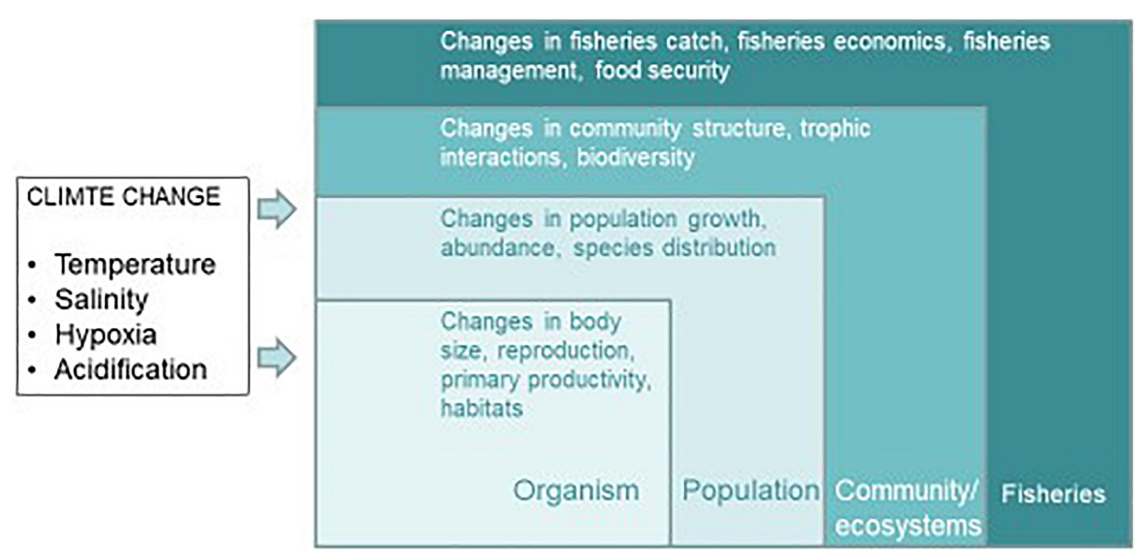

FIGURE 2 | Climate change impacts on marine ecosystems and goods and services provided to human society. Figure adopted from Sumaila et al. (2019).

with changes to physiological function and behavior shaped by their evolutionary history (Doney et al., 2012; Somero, 2012). For example, changes in temperature-e.g., ocean warmingthat go beyond an organism's optimal range will initiate physiological responses that may affect biological performance including growth, reproduction, and survival. Climate-related impacts may also lead to shifts in phenology (timing of seasonal biological events). For example, in European waters we have observed shifts in the timing of zooplankton biomass formation in the North Sea (Schlüter et al., 2010), juvenile Atlantic salmon migration (Kennedy and Crozier, 2010; Otero et al., 2014), and general widespread ecosystem shifts across all major taxonomic groups in the United Kingdom (Thackeray et al., 2010). These direct effects may translate into higher levels of biological organization, affecting population dynamics, and ecosystem structure, function, and diversity [e.g., tropicalisation of temperate reefs (Vergés et al., 2019), localized species invasions and extinctions (Philippart et al., 2011)].

The onset of rapid climate-related changes in these ecosystems is increasing pressure on fish stocks, with the potential of extinction for some fish species. Evidence of large-scale shifts in species' distributions to deeper and higher latitudinal waters has already been documented extensively in the past two decades (e.g., Parmesan and Yohe, 2003; Perry et al., 2005; Dulvy et al., 2008), and these climate effects have continued to manifest at the species (Montero-Serra et al., 2015), ecosystem (Frainer et al., 2017), and fisheries levels (Cheung et al., 2013). Swift action is critical at this stage to ensure the longterm sustainability of marine ecosystems and fisheries (Gattuso et al., 2018) and the varied and crucial benefits they provide (Rogers et al., 2014).

\section{HOW ENDING OVERFISHING CAN INCREASE FISH STOCK RESILIENCE UNDER CLIMATE CHANGE}

Ending overfishing results in: the reduction of fishing effort to ensure sustainable levels of fish catch and yield given the management structure in place (e.g., MSY); a healthier, richer ocean with more diverse fish populations; a more complete marine food web with fish of all trophic levels well represented; and a marine ecosystem with healthier, more varied and more complete marine habitats. Based on these four consequences of ending overfishing, we see at least 5 ways in which ending overfishing can increase the resilience of fish stocks and the marine ecosystem in the face of climate change. Three of these increase resilience by leaving more fish in the ocean; maintaining the structure of marine food webs; and ensuring rich and diverse marine habitats and ecosystems. The remaining two help fish stocks and the marine ecosystem by reducing the amount of $\mathrm{CO}_{2}$ in the atmosphere through the (i) emission of less $\mathrm{CO}_{2}$ by the fishing sector itself; and (ii) sequestration of higher levels of $\mathrm{CO}_{2}$ that more fish in the ocean that ending overfishing entails.

\section{End Overfishing, Increase Fish Abundance of Commercial Stocks}

Overfishing takes too much fish out of a renewable natural capital just like withdrawing more money out of a bank account than the savings can generate annually. And just like a bank account, taking more than the annual yield that a fish stock can generate makes the system more vulnerable; the fish stocks and the marine ecosystem would be more vulnerable to change even without a stressor such as climate change. Overfishing has been widely accepted as a direct pressure and major risk to marine environments and ocean health, drastically reducing fish biomass in the ocean (Pauly et al., 2005; Halpern et al., 2015).

\section{End Overfishing, Protect the Integrity of Marine Food Webs}

Overfishing has already done considerable damage to ecosystems and has resulted in trophic cascades (i.e., restructuring of the food chain). It takes too many large individuals from higher trophic levels and high value fish out of the marine ecosystem, going from the highest trophic level and most valuable species at the time they are fishing resulting in serial depletion and fishing down marine food webs (Pauly et al., 2005). These all 
serve to weaken fish stocks and make them vulnerable to all sorts of stressors including climate change. Climate-related impacts on marine ecosystems affect natural and human elements of ocean health. Changes in species' distribution and abundance will increase local invasions and extinctions, redistributing marine biodiversity and its composition (Cheung et al., 2009; Pecl et al., 2017; Sunday et al., 2017). Subsequently, this will affect marine ecosystem goods and services, including food security and dependent coastal communities (Halpern et al., 2012; Lam et al., 2014; Sumaila et al., 2019). Furthermore, the increased variability of environmental change will also increase the variability-and decrease the predictability and reliability — of goods and services to human society (IPCC, 2014).

\section{End Overfishing, Avoid Marine Habitat Degradation}

Indirect pressures of overfishing include habitat degradation (from destructive fishing gear) and pollution (i.e., plastic, oil). Overfishing has already resulted in habitat loss (Daskalov et al., 2007; Halpern et al., 2015). Improving aspects of ocean health such as the condition of marine habitats (corals, seamounts, mangroves and seagrass) can benefit other components of the ecosystem including fish stocks and increase resilience to other pressures-in particular, climate change (Gaines et al., 2018). While pressures and stressors will decrease fish stock abundance and marine ecosystem health, resilience counteracts these negative effects (Halpern et al., 2012).

Habitat loss has implications for marine life, but will also affect other aspects of ocean health such as coastal protection and carbon storage. Hence, the reduction of habitat degradation due to the elimination of overfishing would increase the health of marine ecosystems and the fish stocks they sustain.

\section{End Overfishing, Decrease $\mathrm{CO}_{2}$ Emissions by the Fishing Sector}

The world is awash with fishing vessels. According to the FAO there are currently 4.6 million vessels of various sizes (FAO, 2018). It is estimated that the fishing capacity and effort currently being used to catch fish is between 40 and $60 \%$ of what is needed to fish at MSY. Ending overfishing and rebuilding depleted fish stocks will entail cutting overcapacity by a significant amount. Less fishing vessels chasing few fish in the ocean will mean the fishing sector, which is credited with emitting at least $1 \%$ of global $\mathrm{CO}_{2}$ emissions could cut its emissions by at least $50 \%$, thereby contributing to mitigating climate change. This will in turn benefit fish stocks and the marine ecosystem.

\section{End Overfishing, Increase Fish Biomass and $\mathrm{CO}_{2}$ Sequestration by Marine Life}

Maintaining healthier fish stocks imbedded in a full functioning ocean ecosystem and habitat is important for planetary function-e.g., carbon storage, coastal protection/erosion. The role of the oceans in the regulation of the global carbon cycle is well known (Rogers et al., 2014). It is estimated that the ocean contains about 38,000 Gigatonnes (Gt) of carbon, and this is by far the largest reservoir of carbon in the Earth system (Houghton, 2007). Approximately 6,000 Gt of carbon also lies in marine sediments (Houghton, 2007). Estimates of the flux

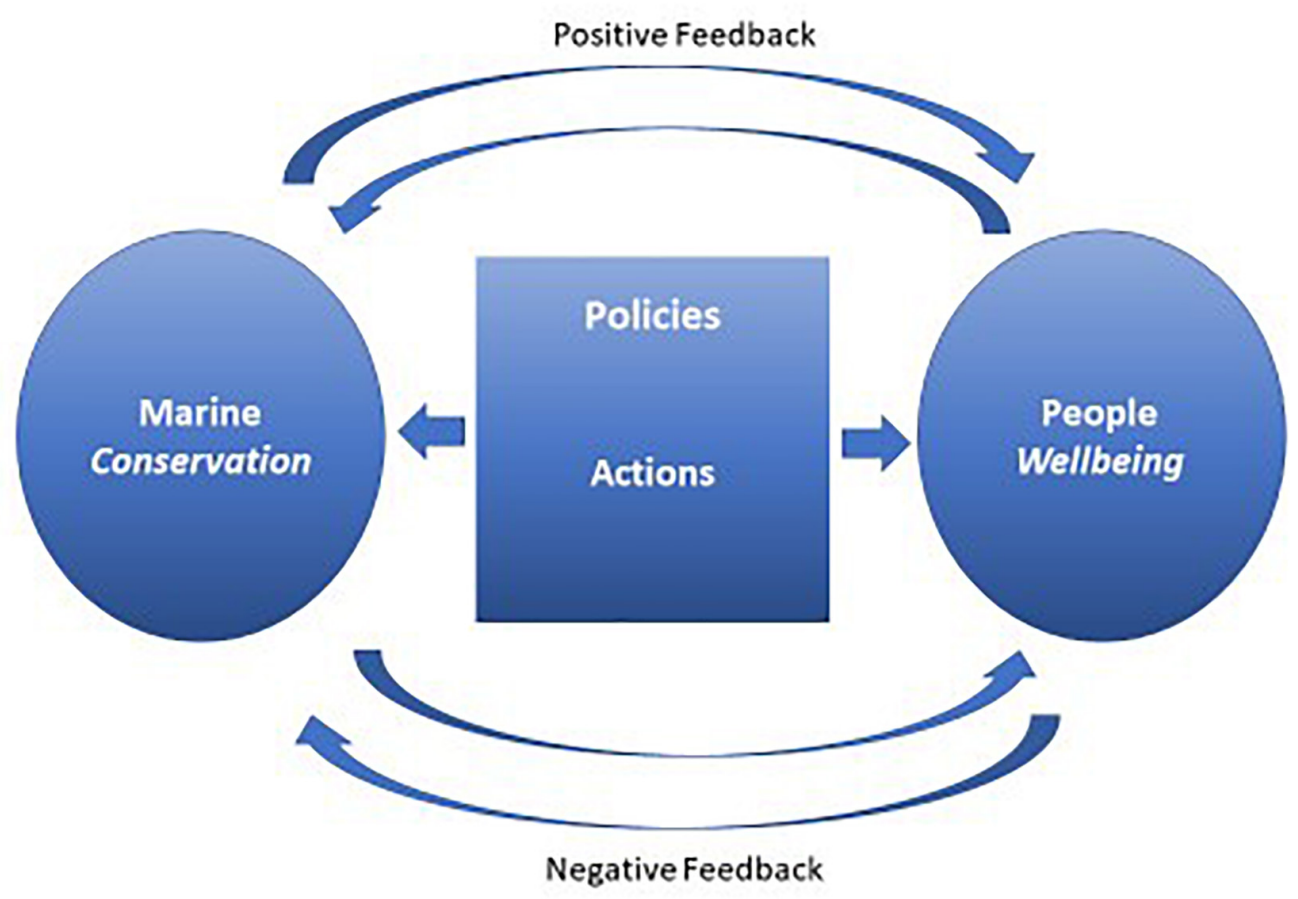

FIGURE 3 | Ending overfishing requires positive feedback between people and the ocean. 
of carbon from the surface ocean to intermediate depths and the deep ocean vary but come from both vertical mixing and the sinking of organic primary production (Houghton, 2007). The oceans are thought to have been the only net sink of human $\mathrm{CO}_{2}$ emissions over the last 200 years with terrestrial ecosystems likely to have been a net emitter (Sabine et al., 2004). By capturing and storing carbon that would otherwise enter the atmosphere and contribute to climate change (Rogers et al., 2014), healthy fish stocks and marine ecosystems can help to mitigate global warming, which in turn protects the ocean and makes marine life more resilient, in a cyclic positive feedback loop (Figure 3).

Climate change and overfishing are working together to accelerate the decline of ocean health putting marine ecosystems and the goods and services provided to society at risk. Ending overfishing would reduce the cumulative pressures on the ocean and increase its resilience, partly mitigating the effects of climate change. Current literature suggests that many possible mechanisms and solutions to adjust the current structure and narrative of fisheries to reduce the pressures on marine ecosystems as a mitigation tool against climate change (Cheung et al., 2017, 2018; Gaines et al., 2018; Gattuso et al., 2018).

Cheung et al. (2018) explored the extinction risk of overfishing and climate change using IUCN categories and species distribution models. The authors found very high extinction risk for $60 \%$ of assessed species with high emissions scenarios and no fisheries management change. With improved fisheries management and climate change mitigation the number of species with very high extinction risk is reduced by $63 \%$. Gaines et al. (2018) set out to understand whether reducing overfishing through fisheries management reform will increase fisheries catch, even under high climate change. They found that despite the negative effects of climate change on fish stocks, reducing fishing effort to ensure MSY will result in gains in catch based on the current state of overfished stocks. Efforts to improve management and the health of fish stocks are best met with ocean solutions that combine global and local solutions, and prioritize fully comprehensive assessments that evaluate trade-offs, benefits

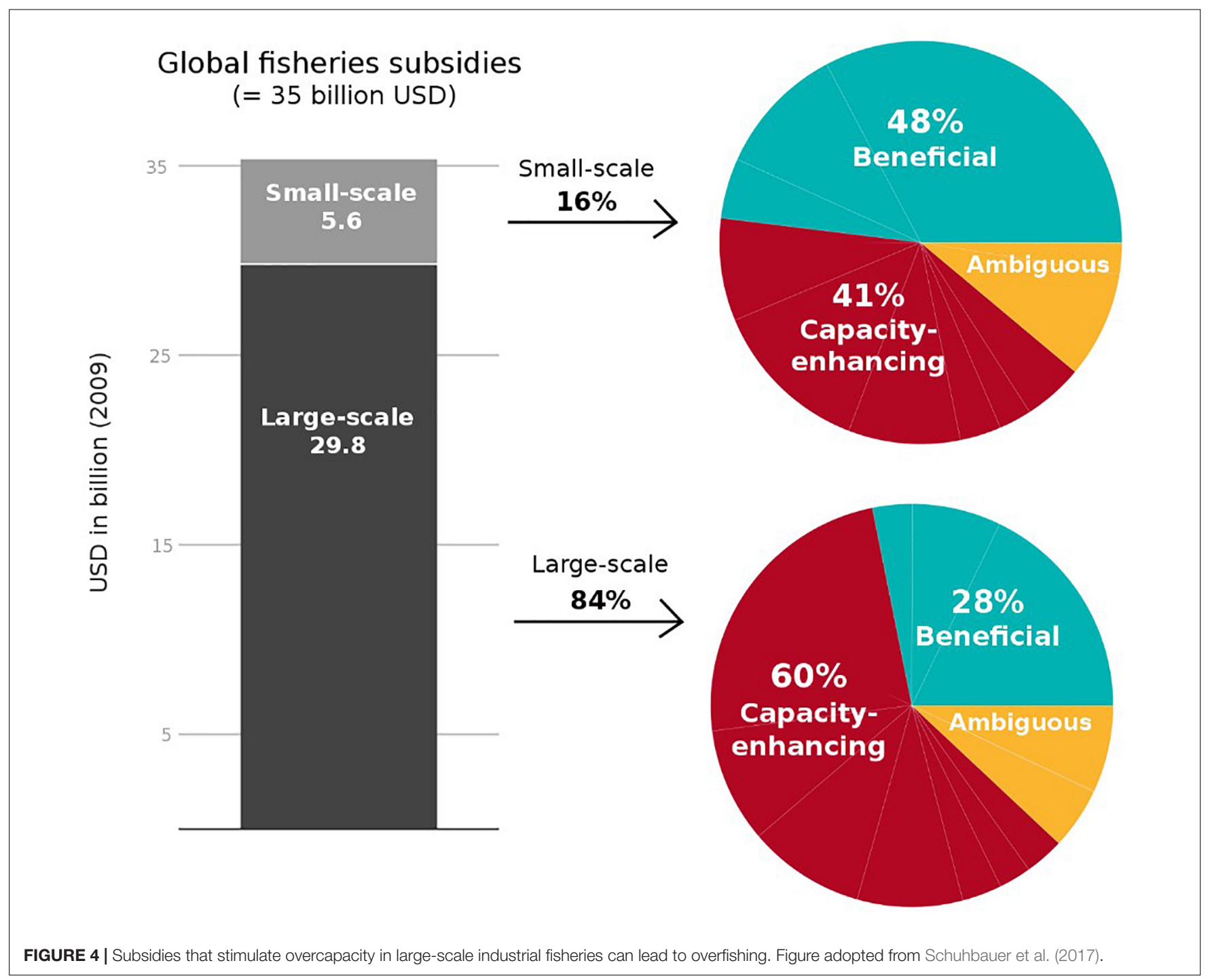


and costs, and the effectiveness of management measures in consideration (Gattuso et al., 2018).

\section{POLICIES AND ACTIONS TO END OVERFISHING}

In general, people overfish because it pays to do so. Hence, the solution to overfishing is to remove the incentive to overfish by making it unprofitable to do so. The organizing framework we propose for ending overfishing is depicted in Figure 3. We assert that the key to successfully ending overfishing is to design policies and take actions that promote positive feedback while dampening negative feedback between people and the ocean. Our discussion of specific solutions is couched within this framework.

National, regional and global fisheries management is not anywhere close to fully effective (Pitcher et al., 2009). Ineffective management reinforces negative feedback from people to nature because our tendency to race for the fish is not managed effectively resulting in overfishing, which makes fish more scarce, aggravating the need to race for the fish even harder with time. While national management is important, regional and global management is also critical because many fish stocks are shared, transboundary, and highly migratory, straddling both EEZs and the high seas. A recent example of ineffective management was provided at last December's AGRIFISH Council in Brussels. This is an annual gathering where EU fishing quotas are allocated behind closed-door. At this particular meeting fisheries ministers agreed to quotas that were a whopping 300,000 t above scientific advice for the North East Atlantic in 2019. Such an action will not be taken in a well-managed fishery. Clearly, improving fisheries management by avoiding such actions would address current overfishing in many fisheries in the EU (and around the world).

Currently most fisheries subsidies are harmful in that they stimulate overcapacity and overfishing (Sumaila et al., 2019), which reinforces negative feedback from nature to people and vice versa. As fish stocks get depleted partly due to subsidies, the fish available to feed people diminishes making people more desperate to catch whatever they can-further aggravating the depletion and desperations. What is more, most of the subsidies provided to fishing sector go to largescale industrial fisheries to the detriment of small-scale fishers (Schuhbauer et al., 2017; Figure 4).

Designating adequate and high quality marine protected areas is a viable and effective strategy for tackling overfishing, and also provides many ancillary benefits to ocean health. Marine reserves that prevent fishing activities can protect important habitat refuges for fish populations and reducing the probability of overfishing (e.g., Afonso et al., 2011). Furthermore, it protects habitats from destructive fishing gear (McLeod et al., 2009; Green et al., 2014), improving overall biodiversity and fisheries-related indicators of ocean health. Subsequently, marine reserves will improve other aspects of ocean health that directly address climate change mitigation (Roberts et al., 2017), specifically: carbon sequestration and storage by protecting critical habitat (e.g., reefs, seagrass beds, kelp); and reducing coastal erosion due to sea level rise by preserving safeguarding habitats.

\section{CONCLUDING REMARKS}

The combination of overfishing and climate change is deadly for fish stocks and marine ecosystems, and just like climate change mitigation will help the long term sustainability of the marine ecosystem. Ending overfishing would enable more effective conservation and sustainable use of marine fish and ecosystems, making it more resilient to climate change.

Reducing exploitation rates to end overfishing has been widely discussed as a viable climate change mitigation strategy. The MSY of fisheries is projected to generally decrease with climate change, yet some areas will face increases (i.e., temperate and polar regions) while others will see major declines (i.e., tropical regions) (Cheung et al., 2010). Despite the historical global spatial expansion of fisheries and its extensive footprint on marine ecosystems (Halpern et al., 2008; Swartz et al., 2010), current fisheries catch are estimated to be underperforming due to inefficiencies with management, regulation, and compliance. Due to the current inefficiencies and operating at below MSY, improvements in management to achieve MSY would not only increase long-term catch, but actually offset some of the negative effects of climate change on catch (Gaines et al., 2018). For overfished EU fish stocks, this could prove extremely valuable to increase catch by improving management as a climate change adaptation strategy.

Implementing policies, strategies and actions that reinforce positive feedback from people to nature and vice versa would help end overfishing, increasing resilience to climate change as it has been found to help with recovery from extreme climate impacts (O’Leary et al., 2017; Roberts et al., 2017). Therefore, ending overfishing will not only provide more seafood over time but it will also increase fish stock and ocean resilience by helping to reduce $\mathrm{CO}_{2}$ in the atmosphere via the emission of less $\mathrm{CO}_{2}$ by the fishing sector and sequestration of carbon in the deep ocean, strengthening the health and abundance of life in the ocean.

\section{AUTHOR CONTRIBUTIONS}

US conceived the manuscript. US and TT wrote the manuscript. Both authors contributed to the manuscript and approved the submitted version.

\section{FUNDING}

The funding organization is Our Ocean. Award \#0001/2019.

\section{ACKNOWLEDGMENTS}

The authors would like to thank Our Fish for financial support which made this work possible. In addition, US thanks the OceanCanada Partnership supported by the Social Sciences and Humanities Research Council of Canada (SSHRC). Finally, it should be noted that an initial version of this manuscript has been released as a working manuscript at OceanCanada Partnership, University of British Columbia, (US and TT). 


\section{REFERENCES}

Afonso, P., Fontes, J., and Santos, R. S. (2011). Small marine reserves can offer long term protection to an endangered fish. Biol. Conserv. 144, 2739-2744. doi: 10.1016/j.biocon.2011.07.028

Bailey, M., and Sumaila, U. R. (2015). Destructive fishing and fisheries enforcement in eastern Indonesia. Mar. Ecol. Prog. Ser. 530, 195-211. doi: 10.3354/ meps 11352

Brierley, A. S., and Kingsford, M. J. (2009). Impacts of climate change on marine organisms and ecosystems. Curr. Biol. 19, R602-R614. doi: 10.1016/j.cub.2009. 05.046

Cheung, W., Jones, M. C., Reygondeau, G., and Frölicher, T. L. (2018). Opportunities for climate-risk reduction through effective fisheries management. Glob. Chang. Biol. 24, 5149-5163. doi: 10.1111/gcb.14390

Cheung, W. W. L., Jones, M. C., Lam, V. W. Y., Miller, D., Ota, Y., Teh, L., et al. (2017). Transform high seas management to build climate-resilience in marine seafood supply. Fish Fish. 18, 254-263. doi: 10.1111/faf.12177

Cheung, W. W. L., Lam, V. W. Y., Sarmiento, J. L., Kearney, K., Watson, R., and Pauly, D. (2009). Projecting global marine biodiversity impacts under climate change scenarios. Fish Fish. 10, 235-251. doi: 10.1111/j.1467-2979.2008. 00315.x

Cheung, W. W. L., Lam, V. W. Y., Sarmiento, J. L., Kearney, K., Watson, R., Zeller, D., et al. (2010). Large-scale redistribution of maximum fisheries catch potential in the global ocean under climate change. Glob. Chang. Biol. 16, 24-35. doi: 10.1111/j.1365-2486.2009.01995.x

Cheung, W. W. L., Watson, R., and Pauly, D. (2013). Signature of ocean warming in global fisheries catch. Nature 497, 365-368. doi: 10.1038/nature 12156

Chuenpagdee, R., Morgan, L. E., Maxwell, S. M., Norse, E. A., and Pauly, D. (2003). Shifting gears: assessing collateral impacts of fishing methods in US waters. Front. Ecol. Environ. 1, 517-524. doi: 10.1890/1540-9295(2003) 001[0517:SGACIO]2.0.CO;2

Coll, M., Libralato, S., Tudela, S., Palomera, I., and Pranovi, F. (2008). Ecosystem overfishing in the ocean. PLoS One 3:3881. doi: 10.1371/journal.pone.0003881

Colloca, F., Scarcella, G., and Libralato, S. (2017). Recent trends and impacts of fisheries exploitation on mediterranean stocks and ecosystems. Front. Mar. Sci. 4:244. doi: 10.3389/fmars.2017.00244

Daskalov, G. M., Grishin, A. N., Rodionov, S., and Mihneva, V. (2007). Trophic cascades triggered by overfishing reveal possible mechanisms of ecosystem regime shifts. Proc. Natl. Acad. Sci. U.S.A. 104, 10518-10523. doi: 10.1073/pnas. 0701100104

Doney, S. C., Ruckelshaus, M., Emmett Duffy, J., Barry, J. P., Chan, F., English, C. A., et al. (2012). Climate change impacts on marine ecosystems. Ann. Rev. Mar. Sci. 4, 11-37. doi: 10.1146/annurev-marine-041911-111611

Dulvy, N. K., Rogers, S. I., Jennings, S., Stelzenmller, V., Dye, S. R., and Skjoldal, H. R. (2008). Climate change and deepening of the North Sea fish assemblage: a biotic indicator of warming seas. J. Appl. Ecol. 45, 1029-1039. doi: 10.1111/j. 1365-2664.2008.01488.x

FAO (2018). The State of World Fisheries and Aquaculture-Meeting the Sustainable Development Goals. Rome.

Frainer, A., Primicerio, R., Kortsch, S., Aune, M., Dolgov, A. V., Fossheim, M., et al. (2017). Climate-driven changes in functional biogeography of Arctic marine fish communities. Proc. Natl. Acad. Sci. U.S.A. 114, 12202-12207. doi: 10.1073/ pnas. 1706080114

Froese, R., Winker, H., Coro, G., Demirel, N., Tsikliras, A. C., Dimarchopoulou, D., et al. (2018). Status and rebuilding of European fisheries. Mar. Policy 93, 159-170. doi: 10.1016/j.marpol.2018.04.018

Gaines, S. D., Costello, C., Owashi, B., Mangin, T., Bone, J., Molinos, J. G., et al. (2018). Improved fisheries management could offset many negative effects of climate change. Sci. Adv. 4:eaao1378. doi: 10.1126/sciadv.aao1378

Gattuso, J., Magnan, A. K., Bopp, L., Cheung, W. W. L., Duarte, C. M., Hinkel, J., et al. (2018). Ocean solutions to address climate change and its effects on marine ecosystems. Front. Mar. Sci. 5:337. doi: 10.3389/fmars.2018.00337

Green, A. L., Fernandes, L., Almany, G., Abesamis, R., McLeod, E., Aliño, P. M., et al. (2014). Designing marine reserves for fisheries management, biodiversity conservation, and climate change adaptation. Coast. Manag. 42, 143-159. doi: 10.1080/08920753.2014.877763
Gullestad, P., Aglen, A., Bjordal, Å, Blom, G., Johansen, S., Krog, J., et al. (2014). Changing attitudes 1970-2012: evolution of the Norwegian management framework to prevent overfishing and to secure long-term sustainability. ICES J. Mar. Sci. 71, 173-182. doi: 10.1093/icesjms/fst094

Halpern, B. S., Frazier, M., Potapenko, J., Casey, K. S., Koenig, K., Longo, C., et al. (2015). Spatial and temporal changes in cumulative human impacts on the world's ocean. Nat. Commun. 6, 1-7. doi: 10.1038/ncomms8615

Halpern, B. S., Longo, C., Hardy, D., McLeod, K. L., Samhouri, J. F., Katona, S. K., et al. (2012). An index to assess the health and benefits of the global ocean. Nature 488, 615-620. doi: 10.1038/nature11397

Halpern, B. S., Walbridge, S., Selkoe, K. A., Kappel, C. V., Micheli, F., D’Agrosa, C., et al. (2008). A global map of human impact on marine ecosystems. Science 319, 948-952. doi: 10.1126/science.1149345

Houghton, R. A. (2007). Balancing the global carbon budget. Annu. Rev. Earth Planet. Sci. 35, 313-347. doi: 10.1146/annurev.earth.35.031306.140057

IPCC (2014). Climate Change 2014: Impacts, Adaptation, and Vulnerability. Part A: Global and Sectoral Aspects. Contribution of Working Group II to the Fifth Assessment Report of the Intergovernmental Panel on Climate Change. Cambridge: Cambridge University Press.

Jackson, J. B. C., Kirby, M. X., Berger, W. H., Bjorndal, K. A., Botsford, L. W., Bourque, B. J., et al. (2007). Historical overfishing and the recent collapse of coastal ecosystems. Science 629, 1-17. doi: 10.1126/science.105 9199

Kennedy, R. J., and Crozier, W. W. (2010). Evidence of changing migratory patterns of wild Atlantic salmon Salmo salar smolts in the River Bush, Northern Ireland, and possible associations with climate change. J. Fish Biol. 76, 1786-1805. doi: 10.1111/j.1095-8649.2010.02617.x

Lam, V. W. Y., Cheung, W. W. L., and Sumaila, U. R. (2014). Marine capture fisheries in the Arctic: winners or losers under climate change and ocean acidification? Fish Fish. 17, 335-357. doi: 10.1111/faf.12106

Le Quesne, W. J. F., and Jennings, S. (2012). Predicting species vulnerability with minimal data to support rapid risk assessment of fishing impacts on biodiversity. J. Appl. Ecol. 49, 20-28. doi: 10.1111/j.1365-2664.2011.02087.x

McLeod, E., Salm, R., Green, A., and Almany, J. (2009). Designing marine protected area networks to address the impacts of climate change. Front. Ecol. Environ. 7:362-370. doi: 10.1890/070211

Montero-Serra, I., Edwards, M., and Genner, M. J. (2015). Warming shelf seas drive the subtropicalization of European pelagic fish communities. Glob. Chang. Biol. 21, 144-153. doi: 10.1111/gcb.12747

O’Leary, J. K., Micheli, F., Airoldi, L., Boch, C., De Leo, G., Elahi, R., et al. (2017). The resilience of marine ecosystems to climatic disturbances. Bioscience 67, 208-220. doi: 10.1093/biosci/biw161

Otero, J., L'Abée-Lund, J. H., Castro-Santos, T., Leonardsson, K., Storvik, G. O., Jonsson, B., et al. (2014). Basin-scale phenology and effects of climate variability on global timing of initial seaward migration of Atlantic salmon (Salmo salar). Glob. Chang. Biol. 20, 61-75. doi: 10.1111/gcb.12363

Parmesan, C., and Yohe, G. (2003). A globally coherent fingerprint of climate change impacts across natural systems. Nature 421, 37-42. doi: 10.1038/ nature 01286

Pauly, D., Watson, R., and Alder, J. (2005). Global trends in world fisheries: impacts on marine ecosystems and food security. Philos. Trans. R. Soc. B Biol. Sci. 360, 5-12. doi: 10.1098/rstb.2004.1574

Pecl, G. T., Araújo, M. B., Bell, J. D., Blanchard, J., Bonebrake, T. C., Chen, I., et al. (2017). Biodiversity redistribution under climate change: impacts on ecosystems and human well-being. Science 355, 9214. doi: 10.1126/science. aai9214

Perry, A. L., Low, P. T., Ellis, J. R., and Reynolds, J. D. (2005). Climate change and distribution shifts in marine fishes. Science 308, 1912-1915. doi: 10.1126/ science. 1111322

Philippart, C. J. M., Anadón, R., Danovaro, R., Dippner, J. W., Drinkwater, K. F., Hawkins, S. J., et al. (2011). Impacts of climate change on European marine ecosystems: observations, expectations and indicators. J. Exp. Mar. Bio. Ecol. 400, 52-69. doi: 10.1016/j.jembe.2011.02.023

Pitcher, T., Kalikoski, D., Pramod, G., and Short, K. (2009). Not honouring the code. Nature 457, 658-659. doi: 10.1038/457658a

Pörtner, H.-O., Karl, D. M., Boyd, P. W., Cheung, W. W. L., LLuch-Cota, S. E., Nojiri, Y., et al. (2014). IPCC - Chapter 6 ocean systems. clim. chang. 2014 
impacts, adapt. vulnerability. Part A Glob. Sect. Asp. Contrib. Work. Gr. II to Fifth Assess. Rep. Intergov. Panel Clim. Chang. 14, 411-484.

Roberts, C. M., O'Leary, B. C., McCauley, D. J., Cury, P. M., Duarte, C. M., Lubchenco, J., et al. (2017). Marine reserves can mitigate and promote adaptation to climate change. Proc. Natl. Acad. Sci. U.S.A. 114, 6167-6175. doi: 10.1073/pnas.1701262114

Rogers, A. D., Sumaila, U. R., Hussain, S. S., and Baulcomb, C. (2014). The High Seas and Us: Understanding the Value of High-Seas Ecosystems. Oxford, England: Global Ocean Commission.

Sabine, C. L., Feely, R. A., Gruber, N., Key, R. M., Lee, K., Bullister, J. L., et al. (2004). The oceanic sink for anthropogenic $\mathrm{CO}_{2}$. Science 305, 367-371. doi: $10.1126 /$ science. 1097403

Schuhbauer, A., Chuenpagdee, R., Cheung, W. W. L., Greer, K., and Sumaila, U. R. (2017). How subsidies affect the economic viability of small-scale fisheries. Mar. Policy 82, 114-121. doi: 10.1016/j.marpol.2017.05.013

Schlüter, M. H., Merico, A., Reginatto, M., Boersma, M., Wiltshire, K. H., and Greves, W. (2010). Phenological shifts of three interacting zooplankton groups in relation to climate change. Glob. Chang. Biol. 16, 3144-3153. doi: 10.1111/j. 1365-2486.2010.02246.x

Somero, G. N. (2012). The physiology of global change?: linking patterns to mechanisms. Ann. Rev. Mar. Sci. 4, 39-61. doi: 10.1146/annurev-marine120710-100935

STECF (Scientific, Technical and Economic Committee for Fisheries) (2019). Monitoring the Performance of the Common Fisheries Policy (STECF-Adhoc-1901). Luxembourg: Publications Office of the European Union.

Sumaila, U. R., Tai, T. C., Lam, V. W. Y., Cheung, W. W. L., Bailey, M., CisnerosMontemayor, A. M., et al. (2019). Benefits of the Paris Agreement to ocean life, economies, and people. Sci. Adv. 5:eaau3855. doi: 10.1126/sciadv.aau3855
Sunday, J. M., Fabricius, K. E., Kroeker, K. J., Anderson, K. M., Brown, N. E., Barry, J. P., et al. (2017). Ocean acidification can mediate biodiversity shifts by changing biogenic habitat. Nat. Clim. Chang. 1, 1-6. doi: 10.1038/nclimate3161

Swartz, W., Sala, E., Tracey, S., Watson, R., and Pauly, D. (2010). The spatial expansion and ecological footprint of fisheries (1950 to present). PLoS One 5:e15143. doi: 10.1371/journal.pone.0015143

Thackeray, S. J., Sparks, T. H., Frederiksen, M., Burthe, S., Bacon, P. J., Bell, J. R., et al. (2010). Trophic level asynchrony in rates of phenological change for marine, freshwater and terrestrial environments. Glob. Chang. Biol. 16, 3304-3313. doi: 10.1111/j.1365-2486.2010.02165.x

Tsikliras, A. C., Dinouli, A., Tsiros, V. Z., and Tsalkou, E. (2015). The mediterranean and black sea fisheries at risk from overexploitation. PLoS One 10:121188. doi: 10.1371/journal.pone.0121188

Vergés, A., McCosker, E., Mayer-Pinto, M., Coleman, M. A., Wernberg, T., Ainsworth, T., et al. (2019). Tropicalisation of temperate reefs: implications for ecosystem functions and management actions. Funct. Ecol. 33, 1000-1013. doi: 10.1111/1365-2435.13310

Conflict of Interest: The authors declare that the research was conducted in the absence of any commercial or financial relationships that could be construed as a potential conflict of interest.

Copyright (c) 2020 Sumaila and Tai. This is an open-access article distributed under the terms of the Creative Commons Attribution License (CC BY). The use, distribution or reproduction in other forums is permitted, provided the original author(s) and the copyright owner(s) are credited and that the original publication in this journal is cited, in accordance with accepted academic practice. No use, distribution or reproduction is permitted which does not comply with these terms. 